Andrzej Sakowicz

\title{
Problematyka odpowiedzialności karnej sędziów stosujących przepisy dekretu o stanie wojennym z mocą wsteczną (Glosa do uchwały SN z dnia 20 grudnia 2007 r., I KZP 37/2007)
}

Keywords: Martial law

\section{Summary}

The decree of the State Council (Rada Państwa) of 12 December 1981 on martial law imposed martial law in Poland and ended Solidarity period in Polish history. Many Solidarity activists were imprisoned and sentenced on the basis of this decree. The penal provisions from this decree were often applied by judges on retroactive basis. The text analyzes the responsibility of judges for these commitments. The Supreme Court passed a sentence on this issue in 2007. The Supreme Court expressed an opinion that judges were obliged to apply retroactive rules. The author does not share this opinion. He analyzes Polish legal acts and the Convention on Human Rights (art. 15). A part of the text is dedicated to Gustaw Radbruch's views about human justice, which in critical situation should have been applied despite the fact that written law is different.

Ze względu na niezamieszczenie w Konstytucji PRL z 1952 r. zakazu tworzenia przepisów karnych z mocą wsteczną (zasady lex retro non agit) oraz brak mechanizmu prawnego umożliwiającego uruchamianie kontroli zgodności przepisów rangi ustawowej z Konstytucją lub z prawem międzynarodowym, a także ze względu na brak regulacji określającej miejsce umów międzynarodowych 
w krajowym porządku prawnym, sądy orzekające w sprawach karnych o przestępstwa z dekretu Rady Państwa z dnia 12 grudnia 1981 r. o stanie wojennym (Dz. U. Nr 29, poz. 154) nie były zwolnione z obowiązku stosowania retroaktywnych przepisów karnych rangi ustawowej.

1. Teza glosowanej uchwały, jak i jej uzasadnienie nie zasługuje na aprobatę, ponieważ pozostaje $\mathrm{w}$ sprzeczności z fundamentalną zasadą prawa karnego lex retro non agit, która mieści się $\mathrm{w}$ „zbiorze” noszącym nazwę prawa człowieka. W zbiorze, który - jak określił G. Radbruch - „stoi ponad wszystkimi pisanymi ustawami i zbiorami praw, ma prawo niezbywalne i odwieczne, które odmawia przestępczym rozkazom tyranów mocy obowiązującej”'. Glosowana uchwała rodzi także sprzeciw w warstwie aksjologicznej prawa karnego, a jednocześnie ukazuje konflikt między prawem pozytywnym a sprawiedliwością, który - niestety - przegrywa sprawiedliwość. Tym samym wyrażony w uchwale pogląd wymaga szerszego omówienia, również z uwagi na fakt, iż dotyka problematycznego zagadnienia, jakim jest „rozliczenie z przeszłością”2

2. Przyczynkiem do wydania uchwały stała się następująca sytuacja procesowa. Otóż Prokurator Instytutu Pamięci Narodowej - Oddziałowej Komisji Ścigania Zbrodni przeciwko Narodowi Polskiemu w Katowicach wnioskiem z 13 lipca 2007 r. wystąpił o zezwolenie na pociągnięcie do odpowiedzialności karnej dwóch sędziów SN w stanie spoczynku „wobec istnienia uzasadnionego podejrzenia" popełnienia zbrodni komunistycznej polegającej na niedopełnieniu obowiązku i bezprawnym pozbawieniu wolności wskazanych we wniosku osób. Miało to nastąpić w związku z nieuwzględnieniem w lutym 1982 r. zażalenia obrońców tych osób na postanowienia sądów niższych instancji o zastosowaniu tymczasowego aresztowania w związku z czynem z art. 46 ust. 1 i 2 dekretu z dnia 12 grudnia 1981 r. o stanie wojennym (Dz.U. Nr 29, poz. 154, z późn. zm.), który w chwili popełnienia nie był przez prawo zabroniony. Prokurator uznał, że zachowanie sędziego nosiło cechy represji politycznej stosowanej wo-

${ }^{1}$ G. Radbruch, Ustawowe bezprawie i ponadustawowe prawo, [w:] M. Szyszkowska, Zarys filozofii prawa, Białystok 1996, s. 242.

2 Odnośnie tego zagadnienia zob. np. A. Czarnota, Moralne i prawne problemy odnoszenia się do przeszłości. Między sprawiedliwościa retrybutywna a dystrybutywną, „Ius et Lex” 2003, nr 1, s. 127-140; idem, Polityka rządów prawa, konstytucjonalizm i problem rozliczeń z przeszłością (uwagi na marginesie ksiażki Dauida Dyzenhausa "Judging the Judges, Judging Ourselves, Truth, Reconciliation and the Apartheid Legal Order”), „Ruch Prawniczy, Ekonomiczny i Socjologiczny” 2000, nr 1, s. 171 i n.; A. Czarnota, P. Hofmański, Prawo, historia i sprawiedliwość, [w:] E. W. Pływaczewski (red.), Aktualne problemy prawa karnego i kryminologii, Białystok 1998, s. 137-159; M. Wyrzykowski, Prawne aspekty rozliczenia przeszłości, [w:] G. Bałtruszajtys (red.), Prawo wczoraj i dziś. Studia dedykowane Profesor Katarzynie SójceZielińskiej, Warszawa 2000, s. 423 i n.; P. Fiedorczyk, Reconciliation with the Communist Past: the Polish Way, Zeitschrift der Savigny-Stiftung für Rechtsgeschichte, Germanistische Abteilung 2008, Band 125, s. 295-312. 
bec osób wskazanych we wniosku za ich przynależność do NSZZ „Solidarność” i było działaniem na ich szkodę, wypełniającym znamiona przestępstwa nadużycia władzy i bezprawnego pozbawiania wolności. Zdaniem wnioskodawcy, zachowanie sędziów wypełniało znamiona przestępstwa $\mathrm{z}$ art. $231 \$ 1$ k.k. i art. 189 $\$ 2$ k.k., w związku z art. $11 \$ 2$ k.k. i art. 2 ust. 1 ustawy z dnia 18 grudnia 1998 r. o Instytucie Pamięci Narodowej - Komisji Ścigania Zbrodni przeciwko Narodowi Polskiemu (Dz.U. Nr 155, poz. 1016, z późn. zm.).

Prezes SN, kierujący pracami Izby Karnej, działając w zastępstwie pierwszego prezesa SN - prezesa Sądu Dyscyplinarnego w sprawach dyscyplinarnych sędziów SN, na podstawie art. $80 \$ 2$ b zd. 1 ustawy z dnia 27 lipca 2001 r. - Prawo o ustroju sądów powszechnych ${ }^{3} \mathrm{w}$ zw. $\mathrm{z}$ art. $8 \$ 1$ ustawy $\mathrm{z}$ dnia 23 listopada 2002 r. o SN ${ }^{4}$, zarządzeniem z dnia 26 lipca 2007 r. odmówił przyjęcia wniosku jako oczywiście bezzasadnego.

Zarządzenie to zaskarżył zażaleniem prokurator IPN, wnosząc o „uchylenie zaskarżonego zarządzenia i przekazanie sprawy Rzecznikowi Dyscyplinarnemu w celu jej przekazania do rozpoznania Sądowi Dyscyplinarnemu przy Sądzie Najwyższym, jako sądowi pierwszej instancji”. Jednak postanowieniem z dnia 28 września 2007 r., SN - Sąd Dyscyplinarny przekazał powiększonemu składowi SN zagadnienie prawne wymagające zasadniczej interpretacji ustawy:

„Czy oczywiste jest, że na gruncie postanowień Konstytucji Polskiej Rzeczypospolitej Ludowej (Dz. U. z 1976 r., Nr 7, poz. 36 ze zm.), zawartych w szczególności w art. 8 ust. 2 i 3 , art. 30 ust. 1 pkt 3 i 8 oraz art. 62, przy jednoczesnym braku regulacji niektórych podstawowych zasad prawnych, sąd rozpoznający sprawę o przestępstwo określone $\mathrm{w}$ dekrecie $\mathrm{z}$ dnia 12 grudnia 1981 r. o stanie wojennym (Dz. U. Nr 29, poz. 154 ze zm.) był zwolniony z obowiązku respektowania:

1) daty wskazanej w organie promulgacyjnym (14 grudnia 1981 r.) jako dnia «prawnego ogłoszenia» tego dekretu w rozumieniu art. 3 ustawy z dnia 30 grudnia 1950 r. o wydawaniu Dziennika Ustaw Rzeczypospolitej Polskiej i Dziennika Urzędowego Rzeczypospolitej Polskiej Monitor Polski (Dz. U. Nr 58, poz. 524 ze zm.),

2) normy art. 61 wymienionego dekretu w części nadającej mu moc wsteczną «od dnia uchwalenia», a jeżeli tak, to na jakiej podstawie prawnej i w jakich okolicznościach?”

3. Odpowiadając na powyższe pytanie, a jednocześnie uzasadniając wskazaną na wstępie tezę uchwały wpisanej do księgi zasad prawnych, która de iure będzie wiązała składy SN w innych sprawach oraz de facto będzie ograniczała rozliczenie sędziów, którzy świadomie wydawali wyroki skazujące na podstawie

3 Dz. U. 2001, Nr 98, poz. 1070 ze zm.

4 Dz. U. 2002, Nr 240, poz. 2052 ze zm. 
przepisów prawa karnego stanowionych z mocą ich wstecznego działania, Sąd Najwyższy podniósł następujące argumenty:

- po pierwsze, SN uznał, że zasada lex retro non agit „nie należała do zasad zakotwiczonych w Konstytucji PRL z 1952 r., ponieważ Polska Rzeczpospolita Ludowa demokratycznym państwem prawnym, w rozumieniu art. 2 Konstytucji RP z 1997 r., nie była"'. Zatem art. 3 ustawy o wydawaniu Dziennika Ustaw oraz art. 61 dekretu o stanie wojennym w części, w której rozciągał zakres czasowy swego obowiązywania od dnia ogłoszenia, nie były niezgodne z Konstytucją PRL. Sędziowie byli więc zobowiązani do stosowania przepisów, nawet gdy regulacje te hołdowały zasadzie nieretroaktywności prawa karnego. Jak podkreśla SN, art. 62 Konstytucji PRL deklarował zasadę niezawisłości sędziów i ich podleganie tylko ustawie, zaś art. 8 ust. 2 i 3 Konstytucji PRL zobowiązywał wszystkie podmioty do przestrzegania prawa PRL (art. 8 ust. 2: „Ścisłe przestrzeganie praw Polskiej Rzeczypospolitej Ludowej jest podstawowym obowiązkiem każdego organu państwa i każdego obywatela”, ust. 3: „Wszystkie organy władzy i administracji państwowej działają na podstawie przepisów prawa”);

- po drugie, zdaniem SN, wyjątek określony w art. 121 k.k. z 1969 r. nie wyłączał możliwości uregulowania zasad odpowiedzialności karnej w innych aktach prawnych, odmiennie od unormowanych w części ogólnej tego kodeksu, a więc także w art.1 k.k. z 1969 r.;

- i wreszcie po trzecie, zasada lex retro non agit wprawdzie została wyrażona $\mathrm{w}$ art. $15 \mathrm{w} \mathrm{zw} . \mathrm{z}$ art. 4 MPPOiP, który został ratyfikowany przez PRL w 1977 r., to jednak brak było jednoznacznego określenia miejsca MPPOiP $\mathrm{w}$ prawie wewnętrznym. Choć $\mathrm{w}$ nauce wyrażano poglądy na temat możliwości bezpośredniego stosowania umów międzynarodowych, judykatura do lat 90. zajmowała stanowisko odmienne. W tym miejscu należy zauważyć, że SN podnosi, iż również obecnie umiejscowienie ratyfikowanych umów międzynarodowych $\mathrm{w}$ hierarchii źródeł prawa nie jest jednoznacznie unormowane przez ustawodawcę i wciąż budzi kontrowersje w doktrynie. Równocześnie SN stwierdza, że na podstawie Konstytucji PRL brak było „mechanizmu prawnego umożliwiającego uruchamianie kontroli zgodności przepisów rangi ustawowej z Konstytucją PRL lub z prawem międzynarodowym, sądy orzekające w sprawach o przestępstwa $\mathrm{z}$ dekretu o stanie wojennym nie były zwolnione $\mathrm{z}$ obowiązku stosowania przepisów (w tym przepisów retroaktywnych) rangi ustawowej”.

${ }^{5}$ Zob. uchwała SN w składzie 7 sędziów z dnia 11 października 2002 r., SNO 29/02, OSN-SD, z. I-II, poz.36. Pogląd taki wyrażany był także w piśmiennictwie prawniczym (zob. A. Wąsek, Glosa do wyroku Sąu Najwyższego z dnia 20 września 1991 r., III KRN 154/91, „Państwo i Prawo” (dalej:PiP) 1993, nr 10, s.114-115 oraz artykuł H. Kmieciaka, W kwestii odpowiedzialności karnej za respektowanie klauzuli o retroakcji dekretu z dnia 12 grudnia 1981 r. o stanie wojennym (art. 61) przy stosowaniu jego przepisów, „Wojskowy Przegląd Prawniczy” (dalej:WPP) 2006, nr 1, s. 30. 
4. Uwagi krytyczne pod adresem rozstrzygnięcia, jakie zapadło w uchwale SN z dnia 20 grudnia 2007 r. należy poprzedzić kilkoma informacjami natury ogólnej. Zauważyć tu trzeba w pierwszej kolejności, że w nocy z 12 na 13 grudnia 1981 r. Rada Państwa na podstawie art. 33 ust. 2 Konstytucji PRL wprowadziła stan wojenny na terytorium PRL. Nastąpiło to w sposób bezprawny, ponieważ Rada Państwa mogła uchwalić tego typu akt tylko i wyłącznie w okresie, kiedy nie obradował Sejm (art. 31 ust. 1 Konstytucji PRL)

Dekret o stanie wojennym z dnia 12 grudnia 1981 r. został opublikowany w Dzienniku Ustaw Nr 29 pod pozycją 154, przy czym organ publikacyjny był datowany na dzień 14 grudnia 1981 r. Współcześnie wiadomo, że druk przedmiotowego Dziennika Ustaw rozpoczęto dopiero 17 grudnia $1981 \mathrm{r}$. i ukończono 18 grudnia 1981 r. W orzecznictwie Sądu Najwyższego (w tym Sądu Najwyższego - Sądu Dyscyplinarnego) wskazuje się, że fakt późniejszego ogłoszenia Dziennika Ustaw Nr 29, zawierającego m.in. dekret o stanie wojennym, stał się znany dopiero po dacie 9 kwietnia 1991 r. (Nr Pr. 147-67/91), po skierowaniu przez Biuro Prawne Urzędu Rady Ministrów w dniu 9 kwietnia 1991 r. (Nr Pr. 147-67/91) do Biura Orzecznictwa Sądu Najwyższego. Dopiero po tej dacie ów fakt stał się podstawą praktyki orzeczniczej jako tzw. propter nova ${ }^{7}$.

Przepis art. 61 dekretu o stanie wojennym stanowił, że wchodzi on w życie „Z dniem ogłoszenia $\mathrm{z}$ mocą od dnia uchwalenia”. Nie pozostawało to w sprzeczności z art. 4 Ustawy z dnia 30 grudnia 1950 r. o wydawaniu Dziennika Ustaw Rzeczypospolitej Polskiej i Dziennika Urzędowego Rzeczypospolitej Polskiej Monitor Polski (dalej: ustawa o wydaniu Dziennika Ustaw), który stwierdzał, że „Akty prawne ogłoszone w dzienniku wchodzą w życie po upływie czternastu dni od dnia ich ogłoszenia, jeżeli same nie stanowią inaczej”" . Również kodeks karny z 1969 r. nie był barierą dla retroakcyjnego działania dekretu o stanie wojennym. Mimo że art. 1 k.k. z 1969 r. stanowił, iż „Odpowiedzialności karnej podlega ten tylko, kto dopuszcza się czynu społecznie

${ }^{6}$ Dz.U. 1976, Nr 7, poz. 36.

7 Zob. np. wyrok Sądu Najwyższego z dnia 17 marca 1992 r. WO 19/92 OSNKW 1992, Nr 9-10, poz. 69.

${ }_{8}$ Zob. w szczególności: J. Kochanowski, T. de Virion, Zagadnienie świadomości bezprawności a odpowiedzialność z dekretu o stanie wojennym, PiP 1983, nr 3, s. 96; J. Kochanowski, T. de Virion, Glosa do wyroku z 1 III 1982, V KRN 50/82, PiP 1982, nr 9, s. 148-149; J. Kochanowski, Z zagadnień ogłoszenia ustawy karnej (Schuldtheorie a zasada lex retro non agit), „Studia Iuridica” 1991, nr XIX, s. 133-140; G. Rejman, Zbrodnie komunistyczne w koncepcji polskiego prawa karnego, „WPP 2006, nr 1, s. 10; $\mathrm{H}$. Kmieciak, $W$ kwestii odpowiedzialności karnej za respektowanie klauzuli o retroakcji dekretu $z$ dnia 12 grudnia 1981 r. o stanie wojennym (art. 61) przy stosowaniu jego przepisów, WPP 2006, nr 1 s. 33; L. Mażewski, Stany nadzwyczajne w Polsce w latach 1918-1989, Toruń 2006, s. 196 i n.; J. Zajadło, Pięć minut antyfilozofii antyprawa. Glosa do uchwały SN z dnia 20 grudnia 2007 r., I KZP 37/07, „Gdańskie Studia Prawnicze - Przegląd orzecznictwa" 2008, nr 1, s. 161-173; W. Zalewski, Glosa do uchwaty SN $z$ dnia 20 grudnia 2007 r., I KZP 37/07, „Gdańskie Studia Prawnicze - Przegląd orzecznictwa” 2008, nr 3, s. 127-139.

9 Dz.U.1950, Nr 58, poz. 524 z późn. zm. 
niebezpiecznego, zabronionego pod groźbą kary przez ustawę obowiązującą w czasie jego popełnienia", to jednak dopuszczał w art. 121, że przepisy części ogólnej k.k. z 1969 r. „stosuje się do przestępstw przewidzianych w innych ustawach, jeżeli ustawy te nie zawierają przepisów odmiennych". To z tego przepisu (a wcześniej z art. 1 kodeksu karnego z 1932 r.) w okresie PRL wywodzono zasadę lex retro non agit, gdyż konstytucja z $1952 \mathrm{r}$. jej nie przewidywała ${ }^{10}$.

Jedyną regulacją prawną, która dawała możliwość kwestionowania zgodności przepisów - art. 3 ustawy o wydaniu Dziennika Ustaw oraz art. 61 dekretu o stanie wojennym - była regulacja przepisu art. $15 \mathrm{w}$ zw. $\mathrm{z}$ art. 4 Międzynarodowego Paktu Praw Obywatelskich i Politycznych (dalej: MPPOiP) z 1966 r. ${ }^{11}$, który PRL ratyfikowała w 1977 r. Przepis art. 15 MPPOiP zakazywał karania na podstawie przepisów karnych retroaktywnych, a art. 4 MPPOiP wykluczał zawieszenie tej zasady nawet $\mathrm{w}$ razie wprowadzenia stanu wyjątkowego. Należy wspomnieć, że Konstytucja PRL stanowiła tylko, że ratyfikowanie i wypowiadanie umów międzynarodowych leży w kompetencji Rady Państwa. Nie zawierała ona natomiast uregulowania co do ewentualnej bezpośredniej mocy obowiązującej umowy międzynarodowej, ani też miejsca i rangi ratyfikowanych umów międzynarodowych $\mathrm{w}$ systemie prawa polskiego, jak np. obecne uregulowanie w art. 91 ust. 1 i 2 Konstytucji Rzeczypospolitej Polskiej z 1997 r.

Niemniej jednak w doktrynie były reprezentowane głosy, że „Konstytucja PRL nie stała i nie stoi na przeszkodzie temu, aby sąd [...] traktat stosował. [...] traktat przecież wiąże PRL"12. Także w orzecznictwie jeszcze w okresie stanu wojennego podniesiono, że „przeciwko wykładni literalnej art. 61 dekretu o stanie wojennym przemawia jego niezgodność z art. 15 ust. 1 Międzynarodowego Paktu Praw Obywatelskich i Politycznych ratyfikowanego przez Polskę 3 marca 1977 r. Art. 4 ust. 2 tego Paktu nie dopuszcza nawet w okresie stanów szczególnych możliwości zawieszenia stosowania art. 15 ust. 1 Paktu statuującego zasadę lex retro non agit"13.

Nie były to poglądy dominujące. Przyjmowano, że art. 8 Konstytucji PRL nakładała na sądy, jako organy państwa, obowiązek „ścisłego przestrzegania praw” PRL (ust. 2) i „działania na podstawie przepisów prawa” (ust. 3), który to obowiązek ciążył odpowiednio także na sędziach w zakresie orzekania, w którym według art. 62 „podlegali tylko ustawom”. Zarazem Konstytucja PRL nie

${ }^{10} \mathrm{~W}$ polskim ustawodawstwie, zasada lex retro non agit, w zakresie, w jakim pokrywała się ona z zasadą nullum crimen nulla poena sine lege zawarta była w art. 98 ust. 2 Konstytucji marcowej z 1921 r., jak i w art. 68 ust. 4 Konstytucji kwietniowej z 1935 r.

${ }^{11}$ Dz. U. 1977, Nr 38, poz. 167. MPPOiP został ratyfikowany przez PRL w 1977 r.

${ }_{12}$ Por. K. Skubiszewski, Prawa jednostki, umowy międzynarodowe i porządek prawny PRL, PiP 1981, nr 7, s. 16.

${ }^{13}$ Wyrok z 8 czerwca 1982 r. Sądu Wojewódzkiego w Olsztynie, II K (8)82, za J. Kochanowski, Z zagadnień ogłoszenia ustawy karnej..., s. 140, przypis 26. 
upoważniała ani sądów, ani sędziów do badania ważności ustanowionego prawa, czuwanie zaś nad jego zgodnością z nią samą powierzała w art. 30 ust. 1 pkt 3 Radzie Państwa.

W jednym z orzeczeń SN wyraził pogląd, który dominował w ówczesnym okresie, że „Konstytucja PRL uchwalona w dniu 22 lipca 1952 r. powierzająca prawo ratyfikowania i wypowiadania umów międzynarodowych Radzie Państwa, tak jak poprzednie konstytucje, wprost nie reguluje wpływu (stosunku) ratyfikowanych norm prawa międzynarodowego na prawo krajowe, a rozstrzygnięcie tego zagadnienia - jak już stwierdzono - ma fundamentalny wpływ na ocenę prawa sądów do stosowania norm prawa międzynarodowego wprost z pominięciem lub z wyprzedzeniem norm prawa wewnętrznego. Z art. 62 Konstytucji wynika jednocześnie, że sędziowie uprawnieni są do stosowania wyłącznie prawa wewnętrznego, stanowionego przez organy konstytucyjne do tego uprawnione, a przede wszystkim ustaw uchwalonych przez Sejm. Konstytucja PRL nie zawiera żadnego przepisu, który wyjaśniałby skuteczność norm prawa międzynarodowego w prawie wewnętrznym, stanowiąc jedynie w art. 30 ust. 1 pkt 8, że Rada Państwa ratyfikuje i wypowiada umowy międzynarodowe. Ratyfikowanie umowy międzynarodowej przez kolegialną głowę Państwa wywołuje skutki tylko w sferze międzynarodowej, polegające na zobowiązaniu się Państwa wobec społeczności międzynarodowej do wprowadzenia norm prawa międzynarodowego do prawa wewnętrznego. Niewprowadzenie ratyfikowanych norm prawa międzynarodowego do prawa krajowego lub nawet dopuszczenie do sprzeczności prawa wewnętrznego z prawem międzynarodowym może być ocenione negatywnie przez społeczność międzynarodową i prowadzić do oceny, iż Państwo dopuszcza się nawet tzw. deliktu międzynarodowego. W świetle jednak przepisów naszej Konstytucji brak jest podstaw do uznania, iż z chwilą ratyfikacji następuje transformacja norm prawa międzynarodowego do prawa wewnętrznego lub przynajmniej, że taką transformację należy domniemywać wobec braku przepisu prawa. Jest to jedynie zobowiązanie się Państwa do wprowadzenia ratyfikowanych norm prawa międzynarodowego do prawa wewnętrznego. Dopóki bowiem normy prawa międzynarodowego nie zostaną, w sposób przewidziany prawem wewnętrznym, wprowadzone do tego prawa, dopóty takim prawem nie stają się, a w konsekwencji nie wiążą sądów"14.

5. Nie można tej ostatniej tezy podzielić ani też zgodzić się z poglądem SN w glosowanej uchwale. Naprzód wypada dodać, że nie ma bardziej jednoznacznego naruszenia stanu bezpieczeństwa prawnego, a przez to i sprawiedliwo-

${ }^{14}$ Postanowienie SN z 25 sierpnia 1987 r. I PRZ 8/87, OSNCP 1987, Nr 12, poz. 199; wyrok NSA - Ośrodek Zamiejscowy we Wrocławiu z 26 sierpnia 1988 r. SA/Wr 773/87, OSP 1990, Nr 10, poz. 355; zob. też M. Marszałek-Kubiak, Umowa międzynarodowa w prawie konstytucyjnym, Warszawa 1997, s. $94 \mathrm{i} \mathrm{n.}$ 
ści, aniżeli naruszenie fundamentalnej zasady lex retro non agit ${ }^{15}$. Jej obowiązywanie $\mathrm{w}$ prawie karnym uzasadnione jest „przede wszystkim wartością, jaką $\mathrm{w}$ państwie prawa stanowi zaufanie obywatela do obowiązującego systemu prawnego i działań państwa, [...] zaufanie do prawa i państwa, są niweczone, gdy nowo ustanowionemu prawu o niekorzystnych dla obywateli następstwach nadaje się moc wsteczną" ${ }^{16}$. Zbieżne poglądy są wyrażane w orzecznictwie TK, który podkreśla, iż zakaz retroakcji jest „konsekwencją zasady ochrony zaufania obywateli do państwa i stanowionego przezeń prawa, i wymaga, aby nie stanowić praw nakazujących stosowanie nowo ustanowionych norm prawnych do zdarzeń, które miały miejsce przed ich wejściem $\mathrm{w}$ życie” ${ }^{\text {”7 }} \mathrm{i}$ „najważniejsze znaczenie ma w dziedzinie prawa karnego"18.

Należy zauważyć, że w orzecznictwie TK, jeszcze przed nowelizacją Konstytucji PRL z 1952 r. $^{19}$, zostało wyrażone stanowisko, że „zasada niedziałania prawa wstecz, jako dyrektywa postępowania skierowana pod adresem organów stanowiących prawo, polega na tym, że nie należy stanowić norm prawnych, które nakazywałyby stosować nowo ustanowione normy prawne do zdarzeń (rozumianych sensu largo), które miały miejsce przed wejściem w życie nowo ustanowionych norm prawnych i z którymi prawo nie wiązało dotąd skutków prawnych normami tymi przewidzianych. W przypadku, gdy ustawodawca nakazuje kwalifikować według norm nowych zdarzenia zaistniałe przed wejściem tych nowych norm w życie, wówczas mamy do czynienia z ustanowieniem norm $z$ mocą wsteczną (z nadaniem nowym normom mocy wstecznej). Norma nie działa wstecz, jeżeli na jej podstawie należy dokonywać kwalifikacji zdarzeń, które wystąpiły po jej wejściu w życie. Przy ustalaniu następstw prawnych zdarzeń, które miały miejsce pod rządami dawnych norm, ale występują w okresie, gdy nowa norma weszła $\mathrm{w}$ życie, należy - zgodnie $\mathrm{z}$ zasadą lex retro non agit - następstwa te określać na podstawie dawnych norm, ale jedynie do czasu wejścia w życie norm nowych [...]. Trybunał Konstytucyjny podziela także utrwalony w doktrynie pogląd, że w razie wątpliwości, co do czasu obowiązywania ustawy, należy przyjąć, że każdy przepis normuje przyszłość, nie zaś przeszłość [...]. Zasada niedziałania prawa wstecz, chociaż nie została wyrażona w Konstytucji PRL, stanowi podstawową zasadę porządku prawnego. Znajduje ona swoje oparcie w takich wartościach, jak bezpieczeństwo prawne i pewność obrotu prawnego oraz poszanowanie praw nabytych" 20 .

${ }^{15}$ Uznanie zasady lex retro non agit za węzłową dla rządów prawa nastąpiło już w okresie Oświecenia, zob. A. Lityński, O prawie cywilnym i karnym od Wieku Światła i Rozumu do spustoszonego stulecia, „Miscellanea Historico-Iuridica”, t. VI, s. 19-20.

${ }^{16}$ W. Wróbel, Zmiana normatywna i zasady intertemporalne w prawie karnym, Kraków 2003, s. 36.

${ }_{17}$ Wyrok TK z dnia 6 lipca 1999 r., sygn. P 2/99, OTK ZU 1999, Nr 5, poz. 103; orzeczenie TK $\mathrm{z}$ dnia 5 listopada 1986 r., sygn. U 5/86, LexPolonica nr 312361.

${ }^{18}$ Wyrok TK z dnia 6 lipca 1999 r., sygn. P 2/99, OTK ZU 1999, Nr 5, poz. 103.

${ }^{19}$ Dz. U. 1989 r., Nr 75, poz. 444.

${ }^{20}$ Wyrok TK z dnia 28 maja 1986 r., sygn. U 1/86, OTK 1986, poz. 2. 
Z kolei w orzeczeniu z 30 listopada 1988 r. (sygn. K 1/88) TK wskazał, że „zasadę niedziałania prawa wstecz Trybunał Konstytucyjny rozumie szerzej, a więc nie tylko jako zakaz stanowienia norm prawnych, które nakazywałyby stosować nowo ustanowione normy prawne do zdarzeń, które miały miejsce przed ich wejściem w życie i z którymi prawo nie wiązało dotąd skutków prawnych (zasada lex retro non agit $\mathrm{w}$ właściwym tego słowa znaczeniu), lecz także jako zakaz stanowienia intertemporalnych reguł, które mają określić treść stosunków prawnych powstałych pod rządami dawnych norm, a trwających w okresie wejścia w życie norm nowo ustanowionych, jeżeli reguły te wywołują ujemne prawne (a w konsekwencji społeczne) następstwa dla bezpieczeństwa prawnego i poszanowania praw nabytych [...]. Zasada ta, jakkolwiek niewyrażona w Konstytucji wprost, z opinii Trybunału Konstytucyjnego w pełnym składzie wynika z konstytucyjnej zasady praworządności materialnej (art. 8 ust. 1) oraz z zasady zaufania obywateli do państwa, która leży u podstawy wielu postanowień Konstytucji (art. 9, art. 20 ust. 2, art. 101, przepisy ustanawiające podstawowe prawa i wolności obywateli i 11 gwarantujące ich ochronę). [...] Zasada praworządności materialnej wymaga, by prawo wyrażało wartości odpowiadające demokratycznemu charakterowi państwa. Zgodnie z brzmieniem art. 8 ust. 1 Konstytucji prawa Polskiej Rzeczypospolitej Ludowej mają być «wyrazem interesów i woli ludu pracującego». Konstytucja odsyła zatem do najbardziej podstawowych wartości uznawanych przez ustrojodawcę państwa socjalistycznego za godne realizacji i ochrony z punktu widzenia ogólnospołecznego; są nimi interes i wola ludu pracującego. Jedną z wartości pochodnych (obok takich, jak sprawiedliwość społeczna, równość praw, humanizm i demokratyzm prawa), związanych z interesami i wolą ludu, którą ma urzeczywistniać prawo, jest bez wątpienia wymóg społecznej stabilności (trwałości) i praw gwarantowanych przez ustawy i związanego z nim bezpieczeństwa prawnego obywateli. Wyraża je i chroni zasada niedziałania prawa wstecz. Będąc elementem zasady praworządności materialnej, sama ma instrumentalny charakter względem wartości nadrzędnych, jakimi są interesy i wola ludu pracującego. Wynika stąd, że ustawodawca, wyrażając te wartości nadrzędne, musi jednocześnie mieć na uwadze, by stanowione przez niego prawa stwarzały poczucie stabilności praw obywateli. Granice tej stabilności wyznaczać może także tylko wola i interesy suwerena [...] Zasada zaufania obywatela do państwa, leżąca u podstawy wymienionych wyżej postanowień Konstytucji i regulowanych nimi instytucji ustroju, jest - podobnie jak zasada praworządności materialnej - zasadą prawnokonstytucyjną, która rodzi określone obowiązki w sferze działalności państwa. W dziedzinie prawodawczej działalności państwa stwarza ona w szczególności obowiązek kształtowania prawa w taki sposób, by nie ograniczać wolności obywateli, jeśli nie wymaga tego ważny interes społeczny lub indywidualny, chroniony Konstytucją, obowiązek przyznawania obywatelom praw $\mathrm{z}$ jednoczesnym ustanowieniem gwarancji realizacji tych praw, obowiązek stanowienia prawa spójnego, jasnego i zrozumiałego dla obywateli, 
wreszcie obowiązek nienadawania przepisom prawnym mocy wstecznej. Gdy idzie o ten ostatni obowiązek zasada zaufania obywatela do państwa wymaga, by mocy wstecznej nie nadawać przepisom, które regulują prawa i obowiązki obywateli i pogarszają ich sytuację prawną. Nie należy także stanowić przepisów, które by $\mathrm{w}$ jakiś sposób ograniczały katalog praw, mających podstawę w Konstytucji lub służącym ich realizacji. Na stabilności i rozwojowym charakterze praw i obowiązków obywateli wspiera się bowiem zaufanie obywateli do państwa i jego społeczna siła. W ten sposób zasada zaufania obywateli do państwa staje się jednocześnie podstawową wartością ogólnospołeczną, do której odsyłają i którą chronią normy ustawy zasadniczej”21.

6. Zasada lex retro non agit nie posiada jednak atrybutu absolutności i zarówno na gruncie prawa polskiego, jak i prawa międzynarodowego, przewidziane są odstępstwa w jej stosowaniu. Jak wiadomo, art. 42 ust. 1 Konstytucji RP z 1997 r. dopuszcza karalność za te czyny, które w czasie ich popełnienia stanowiły przestępstwo $\mathrm{w}$ myśl prawa międzynarodowego. W tym stanie rzeczy „nie będzie więc stanowiło naruszenia normy konstytucyjnej wprowadzenie retroaktywnej penalizacji zachowania, które $\mathrm{w}$ chwili popełnienia nie było zabronione pod groźbą kary przez ustawę, o ile prawo międzynarodowe uznawało to zachowanie za przestępstwo" ${ }^{2}$.Także art. 7 ust. 2 EKPCz stanowi, że „Niniejszy artykuł (tj. art. $7 \mathrm{EKPCz}$ - A.S.) nie stanowi przeszkody w sądzeniu i karaniu osoby winnej działania lub zaniechania, które w czasie popełnienia stanowiły czyn zagrożony karą według ogólnych zasad uznanych przez narody cywilizowane”. Nie można też pominąć art. 15 ust. 2 MPPOiP, który stanowi, że „Nic w niniejszym artykule (art. 15 MPPOiP - A.S.) nie ogranicza sądzenia i karania jakiejkolwiek osoby za jakikolwiek czyn lub zaniechanie, które w chwili ich popełnienia stanowiły przestępstwo w myśl ogólnych zasad prawa uznanych przez społeczność międzynarodową".

Także w literaturze ${ }^{23} \mathrm{i}$ orzecznictwie TK wskazano, że, od zasady nieretroakcji powinno się odstępować wyjątkowo, z bardzo ważnych powodów”24, a „wprowadzenie uzasadnionego względami sprawiedliwościowymi odstępstwa od zasady lex retro non agit wymaga bardzo precyzyjnego określenia przypadków, których odstępstwo to miałoby dotyczyć [...]"25. Odstąpienie, o którym tu mowa, może

\footnotetext{
${ }^{21}$ Wyrok TK z dnia 30 listopada 1988 r., sygn. K 1/88, OTK 1988, poz. 6.

22 W. Wróbel, Zmiana normatywna i zasady intertemporalne w prawie karnym, Kraków 2003, s. 402.

${ }^{23}$ Por. W. Wróbel, Zmiana normatywna..., s. 412-415; na gruncie orzecznictwa ETPCz, zob. w szczególności M. Królikowski, O dopuszczalności retroaktywnego stosowania wykładni w prawie karnym. Przypadek tak zwanych strzelców przy murze berlińskim, [w:] P. Winczorek (red.), Teoria i praktyka wykładni prawa, Warszawa 2005, s. 229-243.

${ }^{24}$ Wyrok TK z dnia 28 maja 1986 r., sygn. U 1/86, OTK 1986, poz. 2.

${ }^{25}$ Wyrok TK z dnia 25 września 1991 r., sygn. S 6/91, OTK 1991, poz. 34.
} 
mieć miejsce, gdy chodzi o działania funkcjonariuszy publicznych w okresie totalitarnym. Jak podnosi W. Wróbel, „wyłączenie zakazu retroaktywności w stosunku do osób sprawujących imperium państwowe (władzę) stanowi gwarancję, że ustawodawca nie pozwoli sobie na naruszenie podstawowych praw jednostki. $\mathrm{W}$ ten sposób spełniony jest także wymóg państwa prawnego w stawianiu granic władzy państwowej w stosunku do jednostki czy też gwarantowaniu wolności praw podstawowych jednostki także przed nadużyciami ze strony państwa [...]. W ten sposób prawo karne spełnia swoją funkcję, informując, iż nieludzka polityka prowadzona na poziomie legislacji nie pozostaje bez kary [...]"26.

Powyższe poglądy TK oraz przedstawicieli doktryny są w pełni czytelne, gdy obracamy się w ramach współczesnych ram prawa pozytywnego. Sytuacja komplikuje się, gdy sięgniemy do regulacji z grudnia $1981 \mathrm{r}$. Bezspornie należy uznać, że Konstytucja PRL nie wyrażała zasady lex retro non agit. Powołanie się na tę zasadę było zatem znacznie utrudnione ${ }^{27}$, aczkolwiek możliwe. Wszakże należy podnieść, że z przepisu art. 1 k.k. z 1969 r. wynikała zasada legalizmu prawa karnego, inaczej określana zasadą nullum crimen sine lege. Jak podnosi M. Królikowski „walor jej ważności wynika z kilku poprzednich założeń, a mianowicie: istnienia reżimu prawa pisanego stanowiącego podstawę dekodowania norm prawa karnego, znaczenia bezpieczeństwa prawnego wynikającego $\mathrm{z}$ literalnego i ścisłego sposobu interpretacji regulacji prawnokarnej, zakazu analogii w zakresie podstaw odpowiedzialności karnej jednostki, zakazu retroaktywnego stosowania prawa wprowadzającego lub podstawy odpowiedzialności karnej jednostki"28.

7. Brak nadaniu zasadzie lex retro non agit rangi konstytucyjnej ma istotne znacznie z punktu widzenia niniejszej sprawy. Przepis art. 1 k.k. z 1969 r., będący źródłem zasady lex retro non agit na gruncie tej ustawy, jak również przepis art. 61 dekretu o stanie wojennym, który naruszał zasadę retroaktywności, były normami tej samej rangi. Artykuł 1 k.k. z 1969 r. nie stanowił - od strony formalnej - przeszkody do stosowania dekretu o stanie wojennym do czynów popełnionych przed jego wejściem w życie. Zdaniem A. Wąska, retroaktywne działanie art. 61 dekretu o stanie wojennym wprawdzie było sprzeczne $\mathrm{z}$ unormowaniem zawartym w art. 1 k.k. z 1969 r., ale dekret ten mógł być (pozornie) uważany za lex posterior w stosunku do k.k. z 1969 r. ${ }^{29}$ Podstawę do takiego

${ }^{26}$ W. Wróbel, Zmiana normatywna..., s. 412-415.

27 A. Gubiński, Glosa do wyroku składu Siedmiu Sędziów z 20 września 1991 r., PiP 1993, nr 10, s. 120.

${ }^{28}$ Zob. M. Królikowski, Glosa do uchwały SN z dnia 20 grudnia 2007 r., I KZP 37/07, s. 7, „Przegląd Sejmowy" 2008, nr 3, s. 243-252, a także uwagi T. Zalasińskiego, Granice obowiązywania konstytucyjnej zasady niedziałania prawa wstecz, s. 243-254.

${ }^{29}$ A. Wąsek, Glosa do wyroku składu Siedmiu Sędziów Sądu Najwyższego z dnia 20 września 1991 r. II KRN 154/91, PiP 1993, nr 10, s. 113. 
argumentu dawał art. 121 k.k. z 1969 r. stanowiący, że przepisy części ogólnej k.k. z 1969 r. „stosuje się do przestępstw przewidzianych w innych ustawach, jeżeli ustawy te nie zawierają przepisów odmiennych". Można oczywiście bronić tezy, że „z art. 121 k.k. musi być wyprowadzona zasada przyjmująca, że w razie wątpliwości, czy ustawa szczególna wyłączyła stosowanie przepisu części ogólnej k.k., należy wyciągnąć wniosek, iż stosowanie przepisu części ogólnej k.k. nie zostało wyłączone. Część ogólna k.k. odgrywa szczególną rolę w systemie obowiązującego prawa karnego i tylko jednoznaczna wypowiedź ustawodawcy w ustawie szczególnej może wyłączyć stosowanie przepisów tej części k.k.” ${ }^{30}$, jak też optować, iż „przepis ten definiował pojęcie przestępstwa dla całego systemu prawa karnego, a używając funktora «tylko» wykluczał możliwość rozszerzenia definicji przestępstwa za pomocą koniunkcji”. Innymi słowy rzecz ujmując, sformułowanie głoszące, że „odpowiedzialności podlega ten tylko kto dopuszcza się czynu [...] zabronionego pod groźbą kary przez ustawę obowiązującą w czasie jego popełnienia” wykluczało interpretację, według której podlega karze „i ten kto dopuszcza się czynu nie zabronionego pod groźbą kary przez ustawę, jeżeli inna ustawa tak stanowi”.

Przepis art. 121 k.k. z 1969 r. używał zatem pojęcia „przestępstwa” w rozumieniu art. 1, stanowiąc, że „przepisy części ogólnej tego kodeksu stosuje się do przestępstw przewidzianych w innych ustawach", a więc do czynów zabronionych przez te ustawy obowiązujące w chwili popełnienia tych przestępstw. Sformułowanie drugiej części tego przepisu „jeżeli ustawy te nie zawierają przepisów odmiennych" (choć pozwalało na to, aby inna ustawa stanowiła np. inne aniżeli w k.k. terminy przedawnienia ścigania przestępstw), to jednakże nie otwierało drogi do stanowienia ustawowego bezprawia naruszającego zasadę lex retro non agit lub inną zasadę określającą istotę przestępstwa - cogitationis poenam nemo patitur ${ }^{31}$. Niemniej jednak wykładnia semantyczna prowadzi do wniosku odmiennego. Treść art. 121 k.k. z 1969 r. otwierała drogę do naruszenia transcedentalnej zasady lex retro non agit na podstawie „ustawowego bezprawia” wbrew normom międzynarodowym ${ }^{32}$.

${ }^{30}$ A. Zoll, Glosa do uchwały składu Siedmiu Sędziów Sądu Najwyższego z dnia 27 września 1985 r., VI KZP 27/85, PiP 1987, nr 2, s. 144.

${ }^{31}$ W. Kulesza, Opinia o tezie odpowiedzi Sądu Najwyższego udzielonej w uchwale z 20.12.2007 r., wpisanej do księgi zasad prawnych (sygn. akt I KZP 37/O7) dotyczącej kwestii odpowiedzialności karnej sędziów stanu wojennego $w$ Polsce, wprowadzonego dekretem z 12.12.1981 r., s. 10-11, w zbiorach autora.

${ }^{32} \mathrm{Na}$ uwagę zasługuje stwierdzanie S. Maurera (Uwagi na temat glosy J. Kochanowskiego i T. de Virion, PiP 1983, nr 1, s. 107), że „Z chwilą ogłoszenia w Dz. U. PRL Paktu, jego przepisy, a wśród nich art. 15 i art. 4 ust. 2 zostały inkorporowane w wewnętrzny system prawny PRL. [...] Do czasu tej inkorporacji zasada «prawo nie działa wstecz» była zasadą kodeksową, stosowaną w myśl art. 121 k.k. także do ustaw szczególnych". Niemniej ustawodawca pozostawił w tymże artykule furtkę umożliwiającą mu odejście od tej zasady w ustawie szczególnej - w przypadku gdy uzna to za stosowne. Inkorporacja art. 4 ust. 2 Paktu w wewnętrzny system prawny PRL oznacza, iż furtka ta została świadomie zatrzaśnięta, gdyż Polska wyrzekła się tym samym prawa do stanowienia przepisów karnych z mocą wsteczną. 
Również inni autorzy podnoszą, że w ówczesnym stanie prawnym sądy nie miały warunków do uznania, że art. 61 dekretu o stanie wojennym jest sprzeczny z Konstytucją PRL. W piśmiennictwie podniesiono też, że obecnie łatwo jest wskazywać na ogólnikowość i pokrętność klauzuli z art. 61 dekretu o stanie wojennym, ale wówczas trudno było ją zakwestionować3 ${ }^{33}$. Za takim poglądem optowało również orzecznictwo sądów dyscyplinarnych. W uchwale Powiększonego Składu Sądu Najwyższego z dnia 11 października 2002 r. SNO 29/2002 ${ }^{34}$ nie tylko zaaprobowano powyższe stanowisko, ale wskazano kolejne argumenty, świadczące o braku bezprawności w zachowaniu sędziego, którego sprawa dotyczyła. Identyczne stanowisko zajął również Sąd Najwyższy w uchwale z dnia 13 stycznia 2003 r. $^{35}$, a także Sąd Dyscyplinarny dla Prokuratorów Instytutu Pamięci Narodowej w orzeczeniu z dnia 14 października 2002 r. SDI 1/2002, w którym stwierdzono, że: „Bezpodstawna jest teza o odpowiedzialności prokuratora za naruszenie swoim działaniem zasady lex retro non agit $\mathrm{w}$ wyniku zastosowania normy sformułowanej w art. 61 dekretu o stanie wojennym [...] zgodnie z przyjętymi wtedy regułami wykładni sądy, ani tym bardziej prokuratorzy nie byli władni zakwestionować mocy obowiązującej prawa stanowionego. Brak jest zatem również podstaw do uznania, że prokurator stosując przepisy dekretu o stanie wojennym do czynów popełnionych w dniu 13 grudnia 1981 r. świadomie chciał przekroczyć swoje uprawnienia albo co najmniej przewidywał taką możliwość i na nią się godził”36. Jak podnosi J. Kochanowski, „jeżeli ani w art. 1 k.k. (z 1969 r. - A.S.), ani w art. 15 MPPOiP nie widziano przeszkody do cofającego wstecz działania dekretu, to nie rozstrzygało to jeszcze jego stosunku do innych zasad odpowiedzialności karnej, które zgodnie z [...] art. 121 k.k. miały zastosowanie do przepisów dekretu, i rzecz ważna, nie zostały uchylone" ${ }^{37}$. Autor tej wypowiedzi ma na myśli reakcję między przepisem art. 61 dekretu o stanie wojennym do konstrukcji błędu co do prawa (i koncepcji winy tzw. Schuldtheorie).

8. Czas na konkluzję w zakresie powyższych tez. Nadanie czynom cech bezprawności od dnia uchwalenia, czyli w okresie sprzed opublikowania dekretu o stanie wojennym (chodzi tu o dni 14-17 grudnia 1981 r.), uniemożliwiało jednostkom powzięcie stosownej wiedzy o nadaniu określonym czynom cechy bezprawności. Truizmem jest stwierdzenie, że pozostawało to $\mathrm{w}$ zgodności z zasadami wprowadzania norm do porządku prawnego. Tym samym taki stan prawny spowodował naruszenie przewidzianej w ówczesnym kodeksie

\footnotetext{
${ }^{33}$ A. Gubiński, Glosa do wyroku składu Siedmiu Sędziów z 20 września 1991..., s. 120.

${ }^{34}$ OSN-SD 2002/I-II, poz. 36.

${ }^{35}$ OSN-SD 2003/I, poz. 17.

${ }^{36}$ Zob. uzasadnienie do postanowienia SN z dnia 5 października 2007 r., SND 2/2007, OSNKW

${ }^{37} \mathrm{~J}$. Kochanowski, Z zagadnień ogłoszenia ustawy karnej..., s. 140.
} 2007, Nr 10, poz. 75. 
karnym konstrukcji błędu co do prawa (art. $24 \$ 2$ k.k. z 1969 r.), który prowadził do wyłączenia winy sprawcy, jeżeli ten w sposób usprawiedliwiony nie mógł zapoznać się z treścią zakazu ${ }^{38}$. Organem promulgacyjnym nie był wówczas Dziennik Telewizyjny, radio czy prasa, a jedynie Dziennik Ustaw. Już w 1959 r. S. Rozmaryn podnosił, że „ogłoszenie w Dzienniku Ustaw jest jedyną urzędową formą ogłoszenia ustawy. Ustawa ogłoszona w jakimkolwiek, choćby urzędowym wydawnictwie nie weszłaby w życie, dopóki nie nastąpiło ogłoszenie w Dzienniku Ustaw”. Dopiero zatem wraz z faktyczną publikacją dekretu o stanie wojennym jednostki mogły zapoznać się z normami sankcjonowanymi oraz sankcjami karnymi grożącymi za ich naruszenie. W żadnej mierze nie może ostać się pogląd SN, mówiący, że „Nie można powoływać się na nieświadomość bezprawności czynu, jeżeli określone w ustawie (dekrecie) zakazy, nakazy lub ograniczenia przed ogłoszeniem aktu prawnego w Dzienniku Ustaw podane zostały do wiadomości publicznej przez środki masowego przekazu i jeżeli co do istnienia takich zakazów, nakazów lub ograniczeń - za pośrednictwem tych środków - sprawca czynu miał świadomość lub też świadomość taką mógł mieć (art. $24 \$ 2$ k.k.)"39. Brak prawidłowego ogłoszenia aktu prawnego jest jednym $\mathrm{z}$ powodów wadliwości prawa. L. Fuller wskazuje wyraźnie, że jednym z ośmiu powodów „niemożności sformułowania żadnego prawa w ogóle” jest „nieopublikowanie, a co najmniej nieudostępnienie zainteresowanym postanowień prawnych, którym mają być posłuszni”. Następnie, co należy podnieść, jest działanie prawa $\mathrm{z}$ mocą wsteczną ${ }^{40}$. L. Fuller stwierdza, że „[...] prawo z mocą wsteczną jest czymś monstrualnym. Prawo za pośrednictwem swych przepisów kierować ma ludzkim postępowaniem. Mówienie o kierowaniu lub kontrolowaniu dzisiejszego zachowania przez przepisy, które wprowadzone zostaną w życie jutro, jest czystym werbalizmem"41.

Oczywiście odstępstwo od zasady winy mogło nastąpić zgodnie z art. 121 k.k. z 1969 r., jednak nie nastąpiło. Dlatego też należy uznać, że o ile dekret o stanie wojennym przełamywał bezpośrednio zasadę lex retro non agit, o tyle nie następowało to $\mathrm{w}$ odniesieniu do zasady winy. Słusznie podnosi M. Królikowski, że „istniała [...] możliwość dostrzeżenia braku prawidłowości wprowadzenia przepisów karnych $\mathrm{w}$ dekrecie o stanie wojennym do porządku prawnego $\mathrm{w}$ takim zakresie, $\mathrm{w}$ jakim rodziły one podstawę odpowiedzialności z tytułu czynów popełnionych pomiędzy dniem uchwalenia a dniem ogłoszenia, jeśli nie dniem realnego opublikowania $\mathrm{w}$ perspektywie zasad subiektywnego przypisania sprawstwa i okoliczności wyłączających winę"42. Także SN w jed-

${ }^{38}$ J. Kochanowski, Z zagadnień ogłoszenia ustawy karnej..., s. 140-141; J. Kochanowski, T. de Virion, Glosa do wyroku..., s. 150-151; M. Królikowski, Glosa do uchwały..., s. 9.

${ }^{39}$ Wyrok SN z dnia 1 marca 1982 r., V KRN 50/82, OSNKW 1982, Nr 6, poz. 39.

${ }^{40}$ L. Fuller, Moralność prawa, Warszawa 1978, s. 74.

${ }^{41}$ Ibidem, s. 91.

${ }^{42}$ M. Królikowski, Glosa do uchwały..., s. 9. 
nym z orzeczeń nawiązał do tego wątku. W judykacie z 24 października $1991 \mathrm{r}$. (II KRN 273/91) czytamy: „Dekret o stanie wojennym mógł wejść i wszedł w życie po ukończeniu druku całości numeru i rozkolportowaniu go, a więc najwcześniej 19 grudnia 1981 r., i od tej daty należało liczyć przestępność czynów nim wprowadzonych. Od tego bowiem dnia ów dekret stał się dostępny i wtedy też powstała powinność zapoznania się z jego treścią, wyłączająca nieświadomość bezprawności tych czynów"43.

9. Analiza argumentacji SN w glosowanej uchwale nasuwa wniosek, że mamy do czynienia z regresem filozoficznoprawnym. Sąd Najwyższy, rozstrzygając zagadnienie prawne, opowiedział się li tylko za pozytywistycznym pojmowaniem prawa $\mathrm{z}$ jednoczesnym zanegowaniem istnienia niezbywalnych i transcendentalnych wartości, wartości, które powinny rozstrzygać fundamentalne kolizje norm. Nie ulega wątpliwości, i to nie tylko w czasach współczesnych, że dekret o stanie wojennym stanowi przykład sprzeczności ustawy jako prawa pozytywnego ze sprawiedliwością - jak określa to G. Radbruch - „ «w wymiarze niedającym się znieść», co sprawia, że ustawa jako "niesłuszne prawo» ma ustąpić sprawiedliwości”. Ustawa taka, jako „ustawowe bezprawie”, nie wiąże sędziego, a jeżeli posługuje się on przepisami tej ustawy w wyroku skazującym, „urągającym wszelkiemu pragnieniu sprawiedliwości, to zachodzi obiektywnie nagięcie prawa". Takie zachowanie sędziego, naruszającego zasadę „podległości prawu, dla której służenia wyznaczona została niezawisłość sędziowska” rodzi jego odpowiedzialność karną ${ }^{44}$. Zatem bezprawie pozostaje bezprawiem także wtedy, gdy zostanie wyrażone w formie ustawy, a wydany na podstawie takiego niesprawiedliwego prawa wyrok nie jest prawny, lecz bezprawny ${ }^{45}$.

Zgodzić się należy z G. Radbruchem, że „Istnieją takie zasady prawne, które silniejsze są od każdego przepisu prawnego i w konsekwencji ustawa, która jest

${ }^{43}$ LEX, nr 22068. W innym orzeczeniu czytamy, że „Polska ratyfikowała w $1977 \mathrm{r}$. Międzynarodowy Pakt Praw Obywatelskich i Politycznych, w którego art. 15 sformułowana jest zasada lex retro non agit, gdyż przepis tego artykułu stanowi, że «nikt nie może być skazany za czyn lub zaniechanie, które w myśl prawa wewnętrznego lub międzynarodowego nie stanowiły przestępstwa w chwili ich popełnienia», a zasada ta - jak wynika to $\mathrm{z}$ treści art. 4 cytowanego Paktu - nie może być uchylona nawet «w przypadku, gdy wyjątkowe publiczne niebezpieczeństwo zagraża istnieniu narodu i fakt ten został oficjalnie ogłoszony»", wyrok SN z dnia 17 października 1991 r., II KRN 274/91, OSNKW 1992, Nr 3-4, poz. 19.

${ }^{44}$ W. Kulesza, Opinia o tezie odpowiedzi Sądu Najwyższego..., s. 3.

${ }_{45}$ G. Radbruch, Die Erneuerung des Rechtes. Die Wandlung 2. Jahrgang 1947, s. 9. Cała wypowiedź brzmi: „Die Rechtswissenschaft muss sich wieder auf die jahrtausendalte gemeinsame Weisheit der Antike, des christlichen Mittelalters und des Zeitalters der Aufklärung besinnen, dass es ein höheres Recht gebe als das Gesetz, ein Naturrecht, ein Gottesrecht, ein Vernunftrecht, kurz ein übergesetzliches Recht, an dem gemessen das Unrecht Unrecht bleibt, auch wenn es in die Form des Gesetzes gegossen ist, - vor dem auch das auf Grund eines solchen ungerechten Gesetzes gesprochene Urteil nicht Rechtsprechung ist, vielmehr Unrecht, mag auch dem Richter, eben wegen seiner positivistischen Rechtserziehung, solches Unrecht nicht zur persönlichen Schuld angerechnet werden”. 
z nimi sprzeczna, pozbawiona jest mocy obowiązującej. Zasady te określa się jako prawo natury lub prawo rozumu. $\mathrm{Z}$ pewnością niektóre $\mathrm{z}$ nich otoczone są wątpliwościami, ale $\mathrm{z}$ drugiej strony przez wieki wypracowano ich tak trwały stan i skodyfikowano w Deklaracjach Praw Człowieka i Obywatela w oparciu o tak powszechne porozumienie, że $\mathrm{w}$ odniesieniu do niektórych $\mathrm{z}$ nich tylko z trudem można zachować sceptycyzm" ${ }^{\prime 6}$. Ta myśl jest silnie powiązana $z$ tzw. formułą Radbrucha, stanowiącą, że prawo pozytywne, pozostające z sprzeczności z uniwersalnymi, ogólnoludzkimi i powszechnie przyjętymi normami moralnymi oraz wyłączające bezprawność określonych czynów, powinno być pozbawione ex ante lub ex post mocy obowiązującej ${ }^{47}$. Nadto G. Radbruch głosił, że „konflikt między sprawiedliwością i bezpieczeństwem prawnym należałoby rozwiązać w ten sposób, ażeby prawo pozytywne zagwarantowane przez ustawodawstwo i władzę państwową miało pierwszeństwo również i wtedy, gdy treściowo jest niesprawiedliwe i niecelowe, chyba że sprzeczność ustawy pozytywnej ze sprawiedliwością osiąga taki stopień, że ustawa jako prawo niesprawiedliwe powinna ustąpić sprawiedliwości”"48. Z powyższego wynika, że niezastosowania się do probierza, którym staje się sprawiedliwość, są ostateczne - odmawiające prawu egzystencji.

Koncepcja G. Radbrucha odegrała istotną rolę w procesie rozliczania zbrodniczej przeszłości. Z punktu widzenia niniejszej opinii, szczególnie interesującego materiału dostarcza orzecznictwo sądów niemieckich, zarówno to dotyczące np. bezprawia czynionego przez niemieckich sędziów w okresie narodowego socjalizmu w Niemczech ${ }^{49}$, jak również spraw tzw. strzelców przy Murze Berlińskim (Mauerschützen). Gdy chodzi o drugą grupę spraw, tj. Mauerschützen, podnieść należy, że orzecznictwo sądów niemieckich na początku lat 90. zaakceptowało tzw. formułę Radbrucha w połączeniu z jednoczesnym odwołaniem się do standardów określonych w normach międzynarodowej ochrony praw człowieka,

${ }^{46}$ G. Radbruch, Pięć minut filozofii prawa, tłum. J. Zajadło, „Colloquia Communia” 1988-1989, 6(41)-1(42), s. 62, za: J. Zajadło, Pięć minut antyfilozofii antyprawa..., s. 170.

${ }^{47}$ J. Zajadło, Formuła Radbrucha - geneza, treść, zastosowanie, PiP 2000, nr 6, s. 25-42; J. Zajadło, Formuła Radbrucha Filozofia prawa na granicy pozytywizmu prawniczego i prawa natury, Gdańsk 2001.

${ }^{48}$ G. Radbruch, Ustawowe bezprawie i ponadustawowe prawo, [w:] M. Szyszkowska, Dociekania nad prawem natury, czyli o potrzebach człowieka, Warszawa 1972, s. 147-158.

${ }^{49}$ Tu wskazać należy na wypowiedź J. Friedricha (Freispruch für die Nazi-Justiz. Die Urteile gegen NS-Richter seit 1948. Eine Dokumentation, Berlin 1998, s. 78), który krytykując uwolnienia przez niemiecki powojenny wymiar sprawiedliwości sędziów nazistowskich od odpowiedzialności karnej za wydawanie wyroków realizujących ustawowe bezprawie w stosunku do skazywanych przez nich osób, posłuży się pytaniem, jakie wynikało z formuły Radbrucha i przed którym stawały sądy w rozpatrywanej sytuacji: czy sędziom wykształconym w duchu prawniczego pozytywizmu, nieznającym innego prawa aniżeli ustawowe, można przypisać umyślne czynienie niesprawiedliwości, wtedy, gdy byli egzekutorami ustawowego bezprawia? Autor posługując się stylistyką rzadko spotykaną w prawniczej argumentacji pisze: tak postawione zagadnienie czyni owych sędziów „najgłupszymi pod słońcem”, W. Kulesza, Opinia o tezie odpowiedzi Sądu Najwyższego..., s. 4. 
zwłaszcza Powszechnej Deklaracji Praw Człowieka z 1948 r. (mimo jej formalnie niezobowiązującego charakteru) i MPPOiP (mimo braku aktu formalnej implementacji do porządku prawnego NRD). Skutkowało to uznaniem, że prawo obowiązujące w NRD legitymizowało określony reżim graniczny, ale legitymizacja ta była sprzeczna $z$ uniwersalnymi, ogólnoludzkimi i powszechnie przyjętymi normami moralnymi zwerbalizowanymi w regulacjach międzynarodowych. W konsekwencji przepisy prawa NRD wyłączające bezprawność czynów albo pozbawione były mocy obowiązującej z uwagi na sprzeczność z prawem międzynarodowym, albo przynajmniej należało je interpretować w duchu wykładni przyjaznej prawom człowieka, co umożliwiałoby odpowiedzialność na zasadach ogólnych kodeksu karnego ${ }^{50}$.

Należy podnieść, że w procesach tzw. Mauerschützen pojawił się problem retroaktywnego stosowania prawa. Sąd niemiecki uznawał, że „funkcjonariusze graniczni nie mogą czuć się rozczarowani w swoim zaufaniu do kontynuacji ustawowych regulacji, ponieważ prawo pisane NRD może być interpretowane w sposób przyjazny prawom człowieka. Art. 103 ust. 2 Ustawy Zasadniczej (zawiera zakaz retroaktywności - A.S.) nie chroni zaufania do trwania skutków określonej praktyki państwa i praktyki wykładni prawa" ${ }^{51}$. W innym orzeczeniu stwierdza się, że „działania oskarżonych były sprzeczne z prawem. Nie uprawomocniła ich ani konstytucja, ani praktyka państwa NRD. I nie stoi temu na przeszkodzie także zasada zakazu działania prawa wstecz wyrażona w art. 103 ust. 2 Ustawy Zasadniczej”, ponieważ ich działania pozostają w sprzeczności $\mathrm{z}$ nakazem materialnej sprawiedliwości oraz przestrzeganiem uznanych w prawie międzynarodowym praw człowieka ${ }^{52}$.

Odwołanie się przez skazanych do ETPCz nie przyniosło skutku. Co więcej, ETPCz uznał, że obowiązujące w NRD przepisy konstytucji, kodeksu karnego, ustaw regulujących reżim graniczny i policyjny należy interpretować literalnie w duchu uniwersalnie pojętego państwa prawa. Prowadzi oto do uznania, że w tym przypadku mamy do czynienia z „pewną projekcyjną «nadrzeczywistością» i stosowaniem paradygmatu państwa prawa do realiów faktycznie nigdy nieistniejących"53. Oznacza to, że ETPCz posłużył się nie ustawodawstwem, a wykładnią retroaktywną, związaną z weryfikacją kontekstu aksjologicznego. To, co było rozumiane w praktyce stosowania prawa za prawne, zostaje uznane za bezprawne ${ }^{54}$.

${ }^{50} \mathrm{~J}$. Zajadło, Pięć minut antyfilozofii antyprawa..., s. 165.

${ }^{51}$ Wyrok w sprawie Manfreda Weylanda, za J. Zajadło, Odpowiedzialność za mur. Procesy strzelców przy murze berlińskim, Wyd. Arche, Gdańsk 2003, s. 137-138.

${ }^{52} \mathrm{~J}$. Zajadło, Odpowiedzialność za mur..., s. 165-166.

${ }^{53}$ J. Zajadło, Komentarz do wyroków ETPC w sprawach strzelców przy murze berlińskim, „Ius et Lex” 2003, nr 1, s. 570.

${ }_{54}$ M. Królikowski, O dopuszczalności retroaktywnego stosowania wykładni w prawie karnym..., s. 235. 
ETPCz nie uwzględnił żadnej ze skarg. Sąd w Strasburgu uznał, że byli funkcjonariusze NRD, jak i strażnik graniczny - musieli mieć świadomość, iż łamią prawo, a ich czyny stanowią przestępstwo, za które w przyszłości mogą za to ponieść karę. Jednocześnie ETPCz wskazał, iż czyny skarżących były niezgodne $\mathrm{z}$ obowiązującym $\mathrm{w}$ tym czasie prawem międzynarodowym - chociażby $z$ ratyfikowanym przez NRD - MPPOiP. Mając to na względzie ETPCz uznał, że skazanie komunistycznych przywódców NRD oraz strażnika granicznego - nie było naruszeniem art. $7 \mathrm{EKPCz}^{55}$.

10. Powyższe odniesienia do norm prawa międzynarodowego, jak też stwierdzenie SN w glosowanej uchwale o „braku regulacji określającej miejsce umów międzynarodowych w krajowym porządku prawnym", które skutkowało m.in. wyrażeniem tezy, iż „brak mechanizmu prawnego umożliwiającego uruchamianie kontroli zgodności przepisów rangi ustawowej z Konstytucją PRL lub z prawem międzynarodowym sądy orzekające w sprawach o przestępstwa $\mathrm{z}$ dekretu o stanie wojennym nie były zwolnione $\mathrm{z}$ obowiązku stosowania przepisów (w tym przepisów retroaktywnych) rangi ustawowej", jest konieczne do zajęcia się prawem międzynarodowym.

Rację ma SN twierdząc, że obowiązywanie umów międzynarodowych w systemie prawa polskiego w okresie PRL budziło wątpliwości, jednak czy ów fakt może usprawiedliwić naruszenie fundamentalnych wartości. Współcześnie także kwestia umiejscowienia ratyfikowanych umów międzynarodowych czy też instrumentów prawnych Unii Europejskiej w prawie krajowym nie jest klarowna, ale nikt $\mathrm{z}$ tego faktu nie wyciągnął wniosku o negowaniu czy podważaniu zasady lex retro non agit.

Wprawdzie w okresie PRL dominowało podejście odmawiające normom prawa międzynarodowego mocy wiążącej dla prawa wewnętrznego, dopóki nie zostaną one wprowadzone do tego prawa ${ }^{56}$. Nie był to jednak pogląd monistyczny. S. Rozmaryn, analizując skuteczność umów międzynarodowych w prawie krajowym, podnosił, że milczenie ustawy zasadniczej w przedmiocie miejsca traktatów w systemie prawnym państwa nie przeczy ich skuteczności $\mathrm{w}$ tym systemie, ponieważ są one skuteczne ex proprio vigore. Autor ten dodawał, że w sytuacji, gdy umowa międzynarodowa dotyczy materii zarezerwowanej dla ustaw, to ich skuteczność wymaga nadto ratyfikacji i opublikowania w Dzienniku Ustaw ${ }^{57}$. Inny badacz, tym razem prawa międzynarodowego,

${ }^{55}$ J.Zajadło, Komentarz do wyroków ETPC $w$ sprawach strzelców przy murze berlińskim, „Ius et Lex” 2003, nr 1, s. 570; idem, Odpowiedzialność za mur..., s. 171-229.

${ }^{56}$ P. Daranowski, Pozycja Międzynarodowego Paktu Praw Obywatelskich i Politycznych oraz Europejskiej Konwencji o ochronie praw $i$ wolności podstawowych w polskim systemie prawnym, [w:] T. Jasudowicz, C. Mika (red.), O prawach człowieka. W podwójną rocznicę Paktów. Księga Pamiątkowa w hołdzie Profesor Annie Michalskiej, Toruń 1996, s. 129.

${ }^{57}$ S. Rozmaryn, Skuteczność umów międzynarodowych PRL w stosunkach wewnętrznych, PiP 1962, nr 12, s. 951-964. 
L. Gelberg wskazywał w 1977 r., że umowy międzynarodowe ratyfikowane przez Radę Państwa i ogłaszane w Dzienniku Ustaw mają moc równą innym źródłom prawa $\mathrm{w}$ tym organie promulgacyjnym. Równocześnie L. Gelberg stwierdzał, że $\mathrm{w}$ razie sprzeczności ustawy $\mathrm{z}$ treścią umowy międzynarodowej państwo powinno zapewnić wykonanie tej ostatniej, „gdyż spowodowanie uszczerbku chronionym interesom państwa kontrahenta lub jego obywateli stanowiłoby delikt, za który państwo ponosi odpowiedzialność prawnomiędzynarodową" ${ }^{38}$. Także Z. Resich pisał o szczególnej roli MPPOiP. W 1981 r. stwierdził: „Pakty w hierarchii aktów międzynarodowych regulujących ochronę praw człowieka posiadają pozycję aktu zasadniczego, niemalże konstytucyjnego" ${ }^{29}$.

Powyższe wypowiedzi doktryny, a także fakt publikacji MPPOiP w Dzienniku Ustaw z dnia 29 grudnia 1977 r. prowadzą do oczywistej konkluzji, która została wyrażona pięć miesięcy przed wprowadzeniem stanu wojennego. W numerze lipcowym „Państwa i Prawa” z 1981 r. K. Skubiszewski pisał tak: „Charakter paktu praw obywatelskich i politycznych ONZ jest jasny. Normy tego paktu są dostatecznie precyzyjne, aby sąd lub organ administracyjny mógł je stosować. [...] stosowanie traktatów ex proprio vigore sprawia, że z chwilą ratyfikacji paktu przez Radę Państwa i ogłoszenia go w Dzienniku Ustaw wytworzył się stan prawny pozwalający realizować prawa przewidziane w pakcie bez oglądania się na krajowe prawodawstwo" ${ }^{60}$.

Na koniec należy zwrócić uwagę na tekst zamieszczony w Dzienniku Ustaw z 29 grudnia 1977 r. Stwierdza się, że „W imieniu Polskiej Rzeczypospolitej Ludowej Rada Państwa Polskiej Rzeczypospolitej Ludowej podaje do powszechnej wiadomości: W dniu 19 grudnia 1966 roku został otwarty do podpisu w Nowym Jorku Międzynarodowy Pakt Praw Obywatelskich i Politycznych. Po zaznajomieniu się z powyższym Paktem Rada Państwa uznała go i uznaje za słuszny zarówno $\mathrm{w}$ całości, jak i każde $\mathrm{z}$ postanowień $\mathrm{w}$ nim zawartych; oświadcza, że wymieniony Pakt jest przyjęty, ratyfikowany i potwierdzony, oraz przyrzeka, że będzie niezmiennie zachowywany (podkr. - A.S.). Na dowód czego wydany został Akt niniejszy, opatrzony pieczęcią Polskiej Rzeczypospolitej Ludowej". W tej sytuacji, dokonując ratyfikacji MPPOiP, nastąpiło formalne recypowanie jego postanowień do porządku prawnego PRL. Rada Państwa wyraźnie wskazała, że MPPOiP „będzie niezmiennie zachowywany”, a uznając go „zarówno w całości, jak i każde z postanowień w nim zawartych”, tym samym zobowiązała się oprzeć swój porządek prawny na wyrażonych w nim zasadach. Wynika $\mathrm{z}$ tego fakt, że przepisy MPPOiP miały bezpośrednie zastosowanie $\mathrm{w}$ wewnętrznym porządku prawnym. O ile - co do zasady - sporna była kwe-

\footnotetext{
${ }^{58}$ L. Gelberg, Zarys prawa międzynarodowego, Warszawa 1977, s. 39.

${ }^{59}$ Z. Resich, Międzynarodowa ochrona praw człowieka, Warszawa 1981, s. 59.

${ }^{60}$ K. Skubiszewski, Prawa jednostki, umowy międzynarodowe i porzadek prawny PRL, PiP 1981,
} nr 7, s. 22. 
stia ewentualnego pierwszeństwa norm prawnych zawartych w MPPOiP przed ustawą, o tyle nie powinno budzić wątpliwości, że w wypadku sprzeczności regulacji wewnątrzkrajowych z przepisami MPPOiP, te drugie uzyskiwały przymiot pierwszeństwa, ponieważ miały być „niezmiennie zachowane”.

11. Czas na ostateczne wnioski. Retroaktywne przepisy karne dekretu o stanie wojennym „nigdy nie osiągnęły godności obowiązującego prawa”. Stosowanie tych przepisów, przed „prawnym ogłoszeniem” w organie promulgacyjnym, jakim był Dziennik Ustaw, było naruszeniem nie tylko prawa zagwarantowanego w art. 1 kodeksu karnego z 1969 r., ale także pogwałceniem ówczesnego porządku konstytucyjnego oraz przepisu art. 15 MPPOiP, ponieważ zakaz w nim określony należy do tej kategorii norm prawa międzynarodowego, które w krajowym porządku prawnym państw - sygnatariuszy MPPOiP, nadają się do bezpośredniego stosowania. Inny sposób publikacji ustawy, np. za pomocą środków masowej informacji, nie jest wystarczający i nie może wywierać skutków prawnych. Jest to rzecz oczywista dla prawnika, w szczególności dla sędziego, który wprawdzie związany jest ustawą, ,ale jego rola i godność nie pozwalają, by musiał stosować ustawy, które są oczywiście i rażąco sprzeczne z ideą prawa, normą, która wprost obraża żyjące w narodzie poczucie prawa i bezprawia" ${ }^{61}$. Dlatego też „żaden sędzia nie może powoływać się na ustawę i wydawać na jej podstawie orzeczeń, jeśli jest ona nie tylko niesłuszna, lecz przestępcza”62.

${ }^{61}$ G. Radbruch, Ustawa i prawo, „Ius et Lex” 2002, nr 1, s. 163.

${ }^{62}$ Ibidem, s. 161. 